\title{
The Relative Equality Theory and the Influence of the Unfairness Policy on the Country Finances and the Economics' Welfare
}

\author{
Westi Riani $^{{ }^{*}} \quad$ Sigit Haryadi $^{2 *} \quad$ Nunung Nurhayati ${ }^{1}$ \\ 1.Faculty of Economics and Business, Universitas Islam Bandung, Jalan Tamansari, Bandung 40116, Indonesia \\ 2.Telematics Group, Institut Teknologi Bandung, Jalan Ganesa, Bandung 40132, Indonesia
}

\begin{abstract}
The article is promoting a new formula for the general economics based on the fairness which is relative, namely the relative equality method which appropriates for assessment and treatment the unfair economic policies. Accordingly, here is the explanation of the method of the relative equality and the proofs that the fairness of the economic policies is a compulsion since the more the fairness of the economic policies, the more the health of the Country financially and the Economics' Welfare, contrary, the greater the unfairness, the greater the chances of the crisis of the country. For instance, the unfairness on the context of the relative equality in the tax policy may result in a loss of the Country's income from taxes of more than $50 \%$. And, the unfair spectrum policy may cause a potential declining on the Country revenue, the Gross Domestic Product, and the quality of internet services over $60 \%$. As well as, the unfair labour policy will lead to a potential unemployment rate of more than $4 \%$; even there is a balance in the labour demand and supply.
\end{abstract}

Keywords: fairness, relative, relative equality index, economic policy, finance healthy; Economics' Welfare

DOI: $10.7176 /$ RJFA/11-10-11

Publication date:May $31^{\text {st }} 2020$

\section{Introduction}

A populist country's long-standing economic policy has been warned of causing a state financial problems (Populism 2020), and there are some experts giving an explanation of how a particular country is reforming its economic policies so as to improve its poor economic conditions for the better (Wang, Xiaohu 2015; Mastilo, Z. 2016). It is a question of whether there is a general theory that can be used by all Countries in order to reform the economic policies that can avert its country from the crisis.

The article introduces a new insight into the method of general economic that the level of the fairness of the economic policy is very influential on the State's finances and the welfare of its people. Therefore, the "relative equality" method, the name of the method can be used to plan a new economic policy, to evaluate an existing economic policy, and to treat inappropriate economic policies. In detail, Chapter 2 writes a literature review that discusses the most widely used existing methods, the Gini Coefficient, and the reasons for the need for a new method as proposed in this paper. Then, Chapter 3 write an explanation of the method proposed in this paper, namely the relative equality index, and the recommendation to determine the level of fairness after computing the index, which the "relative equality coefficient". Equally important, the article reports the implementation of the "relative equality" method prove that the fairness of the level of an economic policy has a high correlation with the level of the performance of the Country financial and the people's welfare. In addition, the purpose of a Country policy is to uphold the fairness, since the more the fairness of the Country policies, the more the Country financially and the Economics' Welfare healthy, contrary, the greater the unfairness, the greater the chances of the crisis of the country's finances and the Economics' Welfare. Then, Chapter 4 show the result which is the proofs that the fairness of the economic policies is a compulsion and the fairness of the level of an economic policy has a high correlation with the level of the performance of the Country financial and the Economics' Welfare. In detail, Chapter 4.1 shows that the unfairness of the relative equality in the tax policy will result in a loss of the Country's income from taxes of $-23.39 \%$ until $-62.31 \%$. And, Chapter 4.2 shows that the unfair spectrum policy causing a potential declining on the Country revenue, the Gross Domestic Product from the telecom sector, and the quality of internet services of $64.84 \%$ until $68.42 \%$. As well as, Chapter 4.3 shows that the unfair labour policy will lead to a potential unemployment rate of more than $4.86 \%$, despite there is a balance in the labour demand and supply. And finally, this paper is complemented by discussions and conclusions written in chapters 5 and 6 .

\section{LITERATURE REVIEW}

The Gini coefficient, sometimes referred to as the Gini index or the Gini ratio, is a statistical dispersion measure intended to represent the income distribution of a country's population, which is currently the most commonly used methods which was developed by Italian statistician and sociologist, Corrado Gini, and published in his paper in 1912. In the popular case for the use of the Gini Coefficient at this time is to measure the imbalance that exists between income distribution values. Where, the zero Gini coefficient expresses a situation where everyone has the same income in a country. On the contrary, the one Gini coefficient states that only one person has all income or consumption, and even more none (Investopedia 2020). In the popular case for the use of the Gini Coefficient at 
this time is to measure the imbalance that exists between income distribution values. Where, the zero Gini coefficient expresses a situation where everyone has the same income in a country. On the contrary, the one Gini coefficient states that only one person has all income or consumption, and even more none. As a result of this weakness, there is a difficulty for state policy makers to find out the level of increase or decrease of income inequality of the population, for example the Gini coefficient has changed from $\mathrm{X} \%$ for two years ago, then changed to $\mathrm{Y} \%$ last year, is it not it can be said that there has been a change in the level of inequality or income equality of ( $\mathrm{Y} \%$ - X\%) divided by $\mathrm{X} \%$.

This paper proposes a method that can overcome the weaknesses of the Gini Coefficient, because the formulated formula will produce the same level of equality with the index. Exactly, the equality index of one is indicating the level of equality is $100 \%$, an index equal to 0.9 is indicating an equality level of $90 \%$, and an index equal to 0.75 is an equality level of $75 \%$, and so on. Thus, this method will be widely used in various fields of state policy to analyse the exact rate of change in the economic and prosperity of the country.

\section{THE RELATIVE EQUALITY METHOD}

The paper introduces a novelty into the fairness measurement of the economy that the level of the fairness to be fair since there is fairness in the relative equality even there is inequality in the "self-equality". To explain, the calculation of the people's income equality is referring to the "self-equality", because the process of calculating the index that only accounts the people's income shares. Otherwise, the assessment of the fairness level of the tax policy is the relative equality, since the calculation of the fairness level takes into account the ratio between the tax rates and the people's income shares. To illustrate, see Figure 1.

The "relative equality" method consists of the integral part, the formula that supports the method, namely the relative equality index, and the recommendation to determine the level of fairness after computing the index, which the "relative equality coefficient"

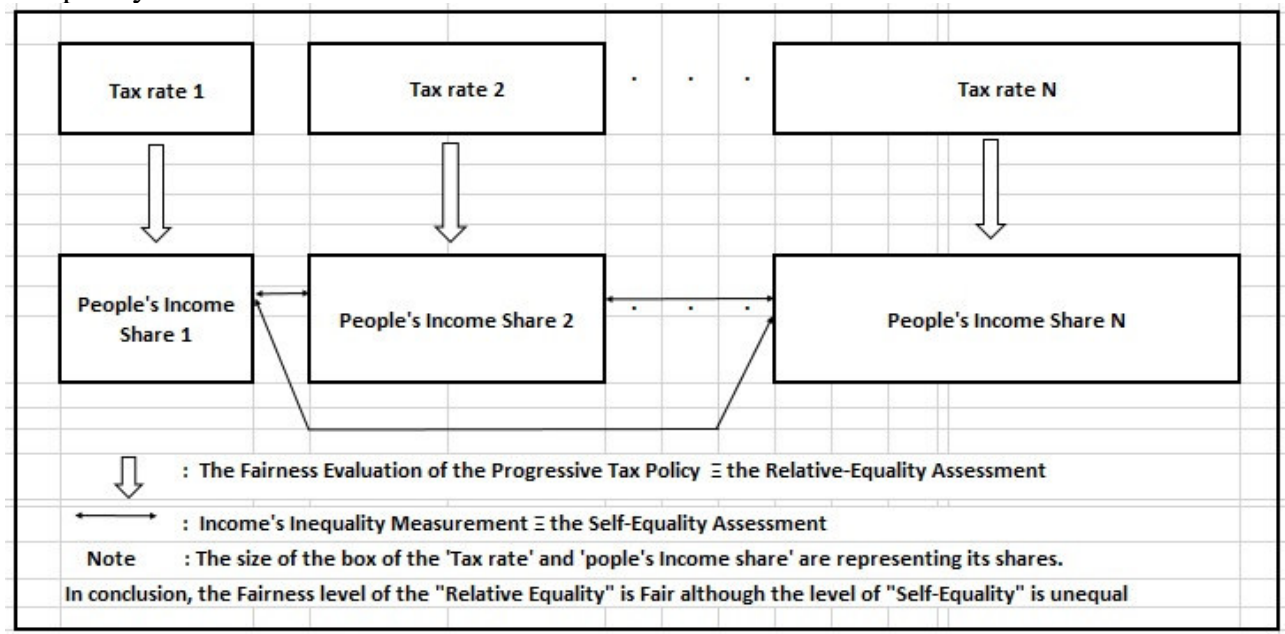

Figure 1. The Fairness level of the "Relative Equality" is fair even the level of "Self-Equality" is unfair

\subsection{The Relative Equality Index}

\subsubsection{The Word Description of the Index (Haryadi 2017)}

The "relative equality index" (REI) is a proper method for the behaviour analysis of a union consisting of a number of elements. Next, REI formula $=\left[1 /\left\{\mathrm{N}^{*}\right.\right.$ (the Fairness + the Inequality) $\left.\}\right]$, where $\mathrm{N}$ is the union's population. Next, the method begins with the calculation of the Share (S). For example, suppose that the total magnitude of union $=150$, then the first element with a magnitude of 30, so that the first Share, $S 1=30 / 150=0.2$. Next, the Fairness $=$ the sum of the squares of the individual share of elements, in above example, $\mathrm{S} 1$ has contributed a part of the fairness $=$ the square of $(0.2)=0.04$; Next, the Inequality $=$ the sum of the squares of the difference of the share. If there are only two elements in the union, then the Fairness $=$ the square of (The first share) + the square of (The second share), and the Inequality = the square of (The second share - The first share) 2 . As well as, if there are three elements in the union, then the fairness = the square of (The first share) + the square of (The second share) + the square of (The third share), and the Inequality $=$ the square of (The second share - The first share) + the square of (The third share - The first share) + the square of (The third share - The second share). Next, determining the level of the fairness, carried out after the completion of the index calculation. Next, there are five levels of the fairness recommendation: Perfect, fair, unbalanced, almost no fairness at all and No fairness at all. To list, the lowest limit value of the Employment Equilibrium index at every level were 1.00 (perfect), 0.75 (fair), 0.5 (unbalanced), and $\{(\mathrm{N}-1) / 2 \mathrm{~N}\}$ (almost no fairness / no fairness at all). 
3.1.2 The Mathematical Formula of the Index (Haryadi, 2017)

This chapter shows the relative equality index is consists of two essential factors which are:

- "The Fairness" (or "the Harmony"). This factor function is to calculate the level of the fairness. Notwithstanding, without "the fairness" part, then the index calculation result will lose its spirit as a method of measuring the level of the fairness.

- "The Inequality" (or the Gradation). This factor function is to get a consistent the fairness index for the calculations of different of the group's number.

Equations 1, 2, 3, and 4 show how to calculate the "share", the "fairness", the "Inequality" and the relative equality index as follows.

$$
\text { The Share }=\mathrm{S}_{\mathrm{i}}=\mathrm{X}_{\mathrm{i}} /\left(\sum_{(\mathrm{i}=1,2 \ldots \mathrm{N})} \mathrm{X}_{\mathrm{i}}\right)
$$

Where $\mathrm{X}_{\mathrm{i}}$ is the element's strength and $\mathrm{N}=$ the population of the union. For example, in the calculation of the "self-equality" of the tax policy, the union is the tax policy, the element's number is the number of the grouping of the people's income (must be the same with the tax rate level), and the element's strength is the people's income share in each group. Otherwise, in the calculation of the "relative equality", the element's strength is the ratio between tax rates to the people's groups and the people's group income shares.

Then, the equation formula for calculating the Share, The Fairness or Harmony, The Inequality or the Gradation, and Relative Equality Index is shown in the following equations

The Fairness $=$ Sum of $($ the square the Share $)=\sum_{(\mathrm{i}=1,2 \ldots \mathrm{N})}\left(\mathrm{S}_{\mathrm{i}}{ }^{2}\right)$ the Inequality $=$ Sum of (the square of the difference of the share)

The Inequality $=\sum(\mathrm{i}=1,2 \ldots \mathrm{N}) \sum_{(\mathrm{j}=1,2 \ldots \mathrm{N})}\left(\mathrm{S}_{\mathrm{i}}-\mathrm{S}_{\mathrm{j}}\right)^{2}$ for $\mathrm{i}>\mathrm{j}$

The Relative Equality Index $=1 /\left[\mathrm{N}^{*}\{\right.$ the Fairness + the Inequality $\left.\}\right]$ (4.a)

The Relative Equality Index $=1 /\left[\mathrm{N}^{*}\left\{\sum_{(\mathrm{i}=1,2 \ldots \mathrm{N})}\left(\mathrm{S}_{\mathrm{i}}^{2}\right)+\sum_{(\mathrm{i}=1,2 \ldots \mathrm{N})} \sum_{(\mathrm{j}=1,2 \ldots \mathrm{N})}\left(\mathrm{S}_{\mathrm{i}}-\mathrm{S}_{\mathrm{j}}\right)^{2}\right.\right.$ for $\left.\left.\mathrm{i}>\mathrm{j}\right\}\right]$ (4.b) For example, the relative equality index for $\mathrm{N}=4$ as follows:

$$
\text { REI (4) }=1 /\left[4\left\{\mathrm{~S}_{1}{ }^{2}+\mathrm{S}_{2}{ }^{2}+\mathrm{S}_{3}{ }^{2}+\mathrm{S}_{4}{ }^{2}+\left(\mathrm{S}_{2}-\mathrm{S}_{1}\right)^{2}+\left(\mathrm{S}_{3}-\mathrm{S}_{1}\right)^{2}+\left(\mathrm{S}_{4}-\mathrm{S}_{1}\right)^{2}+\left(\mathrm{S}_{3}-\mathrm{S}_{2}\right)^{2}+\left(\mathrm{S}_{4}-\mathrm{S}_{2}\right)^{2}+\left(\mathrm{S}_{4}-\mathrm{S}_{3}\right)^{2}\right\}\right]
$$

\subsubsection{The Qualitative Analysis of the Index}

This section writes a qualitative analysis. In conclusion, the relative equality index is appropriate to assess the level of the fairness of the Country policy as a relative equality, which simultaneously reflects the health level of the health of the economic policy, refer to the result that its formula combines two well-known formula: Herfindahl-Hirschman "Concentration" Index (Investopedia 2020; Wikipedia, the free encyclopedia 2020) which equivalent to "the Fairness" part of the relative equality index and the numerator of the Gini "Inequality" Index (The World Bank 2017) which equivalent to "the Inequality" part of the relative equality index. In detail, the history of the Herfindahl-Hirschman and the Gini Index as follows:

- Orris C Herfindahl wrote a dissertation in 1950 at Columbia University, entitled "Concentration in the steel industry", and since then the formula used to be famous, and is still used today to measure the concentration level, as well as being a reference to the competition law in many countries in the world. Competition law task is to maintain market competition by regulating the anti-competitive conduct of companies. Competition law is known as antitrust law in the United States and European-Union, and as anti-monopoly law in the United States and Australia.

- Corrado Gini wrote a paper in the Economic Journal, Blackwell Publishing in 1921, entitled "Measurement of Inequality of Incomes", and from then on, the formula he introduced was still used to measure the level of income inequality. The Gini index is a measurement of the income distribution of a country's residents. This number, which ranges between 0 and 1 and is based on the residents' net income, helps define the gap between the rich and the poor, with 0 representing the perfect equality and 1 representing perfect inequality.

The qualitative explanation of why the relative equality index is should combine Herfindahl-Hirschman Index and Gini Index is as follows:

- "The relative equality index" is a formula for measuring the level of fairness, and then the formula should contain the Herfindahl-Hirschman Index since both formulas contain the same spirit.

- Equally important, that simultaneously the relative equality index also measures the level of fairness that is relative, meaning that should be able to mean that the fairing is still fairly even had been applied over something that is not equal, then in the formula must contain the Gini Index, because the Gini Index proven over a hundred years is relevant for measuring levels of inequality.

Table 1 shows that the table does not want to compare the best of the three indexes, but that it only wants to show that if the "Relative Equality" method has been used, then with reference to the index value which is generated according to the recommendation of the level of justice according to the "Relative Equality" method, only the Relative Equality Index gives the consistent value, while the Herfindahl-Hirschman Index and the Gini Index are not appropriate. For example, the selected conditions are that which fairness level according to the relative equality index is at a perfect level, the lowest index of the fair level, the lowest index of the unbalanced level, and the lowest index of the unfair Level, i.e. when the index is $1.00 ; 0.75 ; 0.5$ and $(\mathrm{N}-1) / 2 \mathrm{~N}$. To explain, the writing of 
the formulas ( 1 - the Herfindahl-Hirschman Index Normalized) and ( 1 - the "original" Gini Index") is so that these two index positions become equivalent to the "Relative Equality Index that aimed at measuring the level of fairness rather than measuring the level of unfairness, which is the negation of the principle of the Herfindahl-Hirschman Index Normalized is measuring the concentration level and the "original" Gini Index" to measure inequality.

Table 1. The Comparation of the Relative Equality Method and the Existing Method

\begin{tabular}{|c|c|c|c|c|c|c|c|c|c|c|c|c|c|}
\hline & \multicolumn{3}{|c|}{$\begin{array}{c}\text { Index at Perfect } \\
\text { Level }\end{array}$} & \multicolumn{3}{|c|}{$\begin{array}{c}\text { The Lowest Index } \\
\text { of Fair Level }\end{array}$} & \multicolumn{2}{c|}{$\begin{array}{c}\text { The Lowest Index } \\
\text { of Unbalanced } \\
\text { Level }\end{array}$} & \multicolumn{2}{c|}{$\begin{array}{c}\text { The Lowest Index } \\
\text { of Unfair Level }\end{array}$} \\
\cline { 2 - 14 } & $\mathrm{N}=2$ & $\mathrm{~N}=3$ & $\mathrm{~N}=4$ & $\mathrm{~N}=2$ & $\mathrm{~N}=3$ & $\mathrm{~N}=4$ & $\mathrm{~N}=2$ & $\mathrm{~N}=3$ & $\mathrm{~N}=4$ & $\mathrm{~N}=2$ & $\mathrm{~N}=3$ & $\mathrm{~N}=4$ \\
\hline S1 & 0.50 & 0.33 & 0.25 & 0.67 & 0.41 & 0.33 & 0.79 & 0.55 & 0.40 & 1.00 & 0.50 & 0.33 \\
\hline S2 & 0.50 & 0.33 & 0.25 & 0.33 & 0.39 & 0.29 & 0.21 & 0.31 & 0.28 & 0.00 & 0.50 & 0.33 \\
\hline S3 & na & 0.33 & 0.25 & na & 0.20 & 0.22 & na & 0.14 & 0.23 & na & 0.00 & 0.33 \\
\hline S4 & na & na & 0.25 & na & na & 0.16 & na & na & 0.09 & na & na & 0.00 \\
\hline $\begin{array}{c}\text { Relative } \\
\text { Equality Index }\end{array}$ & 1.00 & 1.00 & 1.00 & 0.75 & 0.75 & 0.75 & 0.50 & 0.50 & 0.50 & 0.25 & 0.33 & 0.38 \\
\hline $\begin{array}{c}\text { 1 - Herfindahl- } \\
\text { Hirschman } \\
\text { Normalized } \\
\text { Index }\end{array}$ & 1.00 & 1.00 & 1.00 & 0.89 & 0.96 & 0.98 & 0.67 & 0.87 & 0.93 & 0.00 & 0.75 & 0.89 \\
\hline $\begin{array}{c}\text { 1 - "original" } \\
\text { Gini Index }\end{array}$ & 1.00 & 1.00 & 1.00 & 0.83 & 0.67 & 0.45 & 0.71 & 0.27 & 0.09 & 0.50 & 0.25 & 0.17 \\
\hline
\end{tabular}

\subsection{The Relative Equality Coefficient}

The method of the relative equality states that the fairness level of a Country policy as reflected by the relative equality index will influence the level of the performance of the Country financial. Therefore, we need a guideline to determine in how much indexes that the fairness levels of the Country policy are at the level of Perfect, Fair, Unbalanced, and Unfair. These four levels will correlate to the level of the Country finance that has been at the level of Perfect, Healthy, Less Healthy, and Unhealthy.

Table 2. The Relative Equality Coefficient

\begin{tabular}{|c|c|c|c|}
\hline NO & $\begin{array}{c}\text { THE RELATIVE } \\
\text { EQUALITY INDEX }\end{array}$ & $\begin{array}{c}\text { FAIRNESS } \\
\text { LEVEL }\end{array}$ & $\begin{array}{c}\text { THE HEALTHY LEVEL OF THE } \\
\text { ECONOMIC POLICY }\end{array}$ \\
\hline 1 & 1.00 & Perfect & Perfect \\
\hline 2 & $0.75-0.99$ & Fair & Healthy \\
\hline 3 & $0.5-0.74$ & Unbalanced & Unhealthy \\
\hline 4 & $(\mathrm{~N}-1) / 2 \mathrm{~N}-0.49$ & Unfair & No Healthy at All \\
\hline 5 & $\leq(\mathrm{N}-1) / 2 \mathrm{~N}$ & No Fairness at All & .
\end{tabular}

Next, determining the level of the fairness, carried out after the completion of the index calculation. Next, there are five levels of the fairness recommendation: Perfect, fair, unbalanced, almost no fairness at all and No fairness at all. To list, the lowest limit value of the fairness Index at each level was 1.00 (perfect), 0.75 (fair), 0.5 (unbalanced), and $\{(\mathrm{N}-1) / 2 \mathrm{~N}\}$ (= the lowest limit of unfair = no fairness at all). At any rate, these the fairness levels will correlate to the level of the Country finance that has been at the level of Perfect, Healthy, Less Healthy, or Unhealthy.

In detail, Table 2, namely the "Relative Equality Coefficients" shows the recommendation of the determining the fairness level. Of course, this coefficient is not made subjectively but is compiled based on the simulation and analysis in chapter 3 , which proves the alignment between the three parameters which the index produced by the formula, the level of fairness that refers to the coefficient, and the measured economic policy performance.

\section{THE RESULT OF THE RELATIVE EQUALITY METHOD ANALYSIS}

There are two main purposes of the simulation and analysis of assessment of economic policy by using the method of the "Relative Equality", as follows:

- To demonstrate the procedure to use the method, that starting with the formula derivation related the losses caused by the imperfect economic policy, in which each policy may have different formulas, here are shown three formulas of different economic policies. The point of calculation is four things, which the "Relative Equality" index, the level of fairness, the level of the economic policy healthy, and the losses caused by the policy that is not perfect. Note that, the calculation of the relative equality index should use the appropriate formula for the appropriate number of groups $(\mathrm{N})$, as shown in equation 4 and the examples given thereafter. The determination of the level of fairness and the level of healthy applies the table of the "Relative Equality" coefficients provided in table 1 of this article. 
- Giving an understanding that the method of "Relative Equality" is very important related to the assessment and formulation of economic policies that should be fair if not will cause the losses to the country finances and a declining of the public welfare.

\subsection{The Assessment of the Tax Policy}

\subsubsection{The Finance Loss Calculation Caused By the Unfair Tax Policy}

Refer to the method of the relative equality, the relative equality index is equal to one is reflects a perfect level of the fairness, consequently, the finance's loss of the tax policy is equal to zero. Then, referring to the equation 4 , the relative equality index $=1$ when $\mathrm{Si}=\mathrm{Sj}$ at $\mathrm{i}$ and $\mathrm{j}=1,2 . ., \mathrm{N}$. In particular, in the application of the "relative equality" method for the tax policy assessment, "the share", $\mathrm{S}$, is equal to the ratio between tax rates and people's income share. Thus, equation 5 writes this condition mathematically as follows:

$\mathrm{S}_{1}=\mathrm{S}_{2}=\cdots \mathrm{S}_{\mathrm{N}}$

Consequently, equation 6 writes the relative equality index in the fair level as follows:

The relative equality index at the fair level $=1$

The share value in the tax policy assessment is:

\section{$\mathrm{Si}=\mathrm{Pi} / \mathrm{Gi}$}

The notation Pi, which generally reflects "policy granted", in the simulation of the fairness level assessment of the tax policy is the tax rate applicable to each income group, while Gi is the national income share of each income group.

Next, assume that P1 is the tax rate applicable to the group that has the largest income share, then equation 8 writes the properties of the tax rates:

$\mathrm{P}_{1}, \mathrm{P}_{2} \ldots \mathrm{P}_{\mathrm{N}}=\mathrm{k}_{1} \mathrm{P}_{1}, \mathrm{k}_{2} \mathrm{P}_{1} \ldots \mathrm{k}_{\mathrm{N}} \mathrm{P}_{1}$; where $\mathrm{k}_{1} \geq \mathrm{k}_{2} \ldots \geq \mathrm{k}_{\mathrm{N}}$

The income of the Country derived from each income group is proportional to Pi multiplied by Gi, then the total Government income derived from income tax policy is mathematically applicable according to the following equation.

"The Government income from the people income tax" $=\mathrm{P}_{1} \mathrm{G}_{1}+\mathrm{P}_{2} \mathrm{G}_{2} \ldots+\mathrm{P}_{\mathrm{N}} \mathrm{G}_{\mathrm{N}}$

When the fairness level is perfect then the combination of the equations 5 and 7 concludes that.

$\mathrm{S}_{1}=\mathrm{S}_{2}=\cdots \mathrm{S}_{\mathrm{N}}=\mathrm{P}_{1} / \mathrm{G}_{1}=\mathrm{P}_{2} / \mathrm{G}_{2}=\cdots \mathrm{P}_{\mathrm{N}} / \mathrm{G}_{\mathrm{N}}$

Thus, the maximum value if the Government income that is achieved at the maximum level of the fairness is according to the equation 11 as follows:

The maximum government income tax $\cong\left(\mathrm{P}_{1}{ }^{\mathrm{p}}\right)\left(\mathrm{G}_{1}\right)+\left(\mathrm{P}_{1} \mathrm{p} / \mathrm{G}_{1}\right) \mathrm{G}_{2}{ }^{2} \ldots+\left(\mathrm{P}_{1} \mathrm{p} / \mathrm{G}_{\mathrm{N}}\right) \mathrm{G}_{\mathrm{N}}{ }^{2} \quad$ (11)

Where $\mathrm{P}_{1}{ }^{\mathrm{p}}$ is a Country policy which applies to the first group that has a fairness level is perfect, especially, in the tax policy is the tax rate applicable to the richest people group.

Finally, we can count the loss of Government income that occurs due to the not-perfect of the tax policy by calculating the difference between the maximum government income from the income tax (which is obtained if the tax policy in this case is perfectly fair) with the existing income (by applying the current tax policy).

Since the Government income loss will be equal to zero when $\mathrm{P}_{\mathrm{i}}^{\mathrm{p}}=\mathrm{P}_{\mathrm{i}}$, then the value of the country's income loss have a correlation to the "relative equality" index as written in equation 4 . In conclusion, the smaller the relative equality index, the greater the country's income loss.

Table 3. Variations in Government's Tax Income for Various Level of Tax Policy Fairness

\begin{tabular}{|c|c|c|c|c|c|}
\hline \multirow{2}{*}{$\begin{array}{l}\text { Income Equality in } \\
\text { the Country }\end{array}$} & \multirow{2}{*}{$\begin{array}{l}\text { The Number } \\
\text { of Groups }\end{array}$} & \multicolumn{4}{|c|}{$\begin{array}{l}\text { Government's Tax Income (as the portion of National Income); } \\
\text { Assumption: Tax rate Maximum }=30 \%\end{array}$} \\
\hline & & $\begin{array}{l}\text { Tax Policy is } \\
\text { Perfect }\end{array}$ & $\begin{array}{l}\text { Tax Policy } \\
\text { is Fair }\end{array}$ & $\begin{array}{l}\text { Tax Policy is } \\
\text { Unbalanced }\end{array}$ & $\begin{array}{l}\text { Tax Policy is } \\
\text { Unfair }\end{array}$ \\
\hline \multirow{3}{*}{$\begin{array}{l}\text { Income Equality is } \\
\text { Fair }\end{array}$} & 3 & 0.259 & 0.224 & 0.186 & 0.164 \\
\hline & 4 & 0.257 & 0.211 & 0.174 & 0.152 \\
\hline & 5 & 0.256 & 0.203 & 0.169 & 0.145 \\
\hline \multirow{3}{*}{$\begin{array}{l}\text { Income Equality is } \\
\text { Unbalanced }\end{array}$} & 3 & 0.254 & 0.213 & 0.189 & 0.166 \\
\hline & 4 & 0.248 & 0.203 & 0.175 & 0.156 \\
\hline & 5 & 0.249 & 0.205 & 0.171 & 0.144 \\
\hline \multirow{3}{*}{$\begin{array}{l}\text { Income Equality is } \\
\text { Unfair }\end{array}$} & 3 & 0.248 & 0.215 & 0.190 & 0.175 \\
\hline & 4 & 0.257 & 0.211 & 0.181 & 0.158 \\
\hline & 5 & 0.253 & 0.209 & 0.179 & 0.154 \\
\hline
\end{tabular}

4.1.2 The Tax Policy's Assessment Simulation

Table 3 and 4 display the results of simulation calculations. In detail, assume that the 3 countries, which the country $\mathrm{A}$ is the one whose has a fair level of income equality, the country B has an unbalanced income equality, and the country $\mathrm{C}$ has an unfair income equality. And, another assumption is, the constitution of the three countries stipulates that the maximum tax rate is $30 \%$ and the grouping of people related to the income tax policy are 3,4 , 
and 5 groups (the same number of people in the groups).

Table 4. Decreasing of the Government's Tax Income Caused by the Unfair Tax Policy

\begin{tabular}{|c|c|r|r|r|r|}
\hline \multirow{2}{*}{$\begin{array}{c}\text { Income Equality in } \\
\text { the Country }\end{array}$} & $\begin{array}{c}\text { The Number } \\
\text { of Groups }\end{array}$ & \multicolumn{4}{|c|}{$\begin{array}{c}\text { Decreasing of the Government's Tax Income (refer to the case } \\
\text { that Tax Policy is perfect) }\end{array}$} \\
\cline { 2 - 6 } & $\begin{array}{c}\text { Tax Policy is } \\
\text { Perfect }\end{array}$ & $\begin{array}{c}\text { Tax Policy } \\
\text { is Fair }\end{array}$ & $\begin{array}{c}\text { Tax Policy is } \\
\text { Unbalanced }\end{array}$ & $\begin{array}{c}\text { Tax Policy is } \\
\text { Unfair }\end{array}$ \\
\hline $\begin{array}{c}\text { Income Equality is } \\
\text { Fair }\end{array}$ & 3 & $0.00 \%$ & $-13.51 \%$ & $-28.19 \%$ & $-36.68 \%$ \\
\cline { 2 - 6 } & 4 & $0.00 \%$ & $-17.90 \%$ & $-32.30 \%$ & $-40.86 \%$ \\
\hline \multirow{3}{*}{$\begin{array}{c}\text { Income Equality is } \\
\text { Unbalanced }\end{array}$} & 5 & $0.00 \%$ & $-20.70 \%$ & $-33.98 \%$ & $-43.36 \%$ \\
\cline { 2 - 6 } & 3 & $0.00 \%$ & $-16.14 \%$ & $-25.59 \%$ & $-34.65 \%$ \\
\hline \multirow{2}{*}{$\begin{array}{c}\text { Income Equality is } \\
\text { Unfair }\end{array}$} & 4 & $0.00 \%$ & $-18.15 \%$ & $-29.44 \%$ & $-37.10 \%$ \\
\cline { 2 - 6 } & 5 & $0.00 \%$ & $-17.67 \%$ & $-31.33 \%$ & $-42.17 \%$ \\
\cline { 2 - 6 } & 4 & $0.00 \%$ & $-13.31 \%$ & $-23.39 \%$ & $-29.44 \%$ \\
\hline
\end{tabular}

In detail, the calculation shows that the conclusions of applying the method of "relative equality" to the assessment of the tax policy are:

i. The government income is maximum when the level of the fairness of the tax policy is perfect, the lower the level of the fairness the greater the decrease the Government income. In detail, in Country A which has a fair of the income equality, the Government income will reach the highest value $(=0.260$ of the people's income) when the tax policy is perfect in the grouping into two. However, in Country B which has an unbalanced rate of equality of income of the people, the Government income will reach the highest $(=0.254$ of the people's income $)$ value when the tax policy is perfect in the grouping into three, otherwise the Country $\mathrm{C}$ which has an unfair level of income equality equal will reach the highest value $(=0.257$ of the people's income) when the tax policy is perfect in the grouping into three.

ii. At the level of the fairness of the tax policy is unfair will cause the government income fall by more than $-52.16 \%$ compared to the government income at the level of the fairness is perfect, i.e. when there are two levels of tax rate (the government income fall of $-62.31 \%$ in the country $\mathrm{A},-56.22 \%$ in the country $\mathrm{B}$, and $-52.16 \%$ in the country C) ; Meanwhile, if the groups of tax rate are more than two, then the decline of the Country's income when the level of the fairness is at an unfair level will decrease more than $-23.39 \%$ (the minimum of the government income fall at the unfair tax policy of $-28.19 \%$ in the country A, $-25.59 \%$ at country B, the government income fall of $-23.39 \%$ at country C)".

iii. As seen in table III and IV, there is a very strong correlation between the relative equality index and the government income derived from the people's income tax.

iv. There is almost no correlation between the income inequality and the tax policy fairness. This is in accordance with the goal of the method of "relative equality" which is more concerned about the "relative equality" than the "self-equality", especially when the government will make the country policies related to the income inequality.

v. The decrease in the government income due to the reduction of the relative equality index compared to the perfect level of the tax policy is still relatively small when the tax policy is still at a fair level. Contrarily, there was a drastic decline when it was in the unfair level.

vi. The decreasing of the Government income as resulting an unfair tax policy, especially, will be enormous if the number of groupings is only two.

\subsection{The Assessment of the Spectrum Policy}

The spectrum is a scarce resource licensing to the mobile communication providers. In the assessment of the spectrum policy, the disadvantages of the Country due to the unfair policies are in the form: (1) the decrease Government income from corporate taxes, (2) potential decline in GDP, and (3) the potential decline in the quality of internet services.

\subsubsection{The Finance Loss Calculation Caused by the Unfair Spectrum Policy}

In the calculation of the potential losses of the Country, a perfect spectrum policy would occur if the ratio of bandwidth allocated to the provider and the gross revenue of all providers all is the same. Thus, the non-perfect policy indicates the presence of one or more providers who cannot optimize the spectrum allocated to them into their revenues. Of course, it is worth investigating further why this occurs, then if there is no acceptable technical reason, thus this situation indicates that there is the potential loss of the Country, that is, the reduced of Government income from the corporate taxes and reduced the potential GDP obtained from the telecommunications sector. In addition, another aspect to note is the potential decline in the quality of internet services. For example, in these simulations, the perfect spectrum policy will occur if the ratio of bandwidth allocated to the providers and internet 
traffic (Bytes) from all providers is the same. In the same way, the Non-perfect policy indicates that one or more providers are unable to optimize the spectrum allocated to them into the Bytes is indicating a potential decrease in the welfare level of the Country, which is in the form of a reduction in the speed of internet service for the people. Thus, the maximum value if the Government income that is achieved at the maximum level of the fairness is according to the equation 12 as follows:

The Maximum GDP from the Telco sector $\left.\left.=\left(\mathrm{G}_{1}{ }^{\mathrm{p}}\right)+\mathrm{G}_{2}{ }^{\mathrm{p}}\right) \ldots \ldots+\mathrm{G}_{\mathrm{N}} \mathrm{p}\right)$

Where $\mathrm{G}_{\mathrm{i}}^{\mathrm{p}}$ is a provider's gross revenue that has a fairness level of the spectrum policy is perfect.

Assume that provider 1 is the most productive provider, then:

$\mathrm{G}_{1}{ }^{\mathrm{p}}=\mathrm{G}_{1} ;$ And $\mathrm{G}_{\mathrm{i}}^{\mathrm{p}}=\left(\mathrm{G}_{1} \mathrm{P}_{\mathrm{i}}\right) /\left(\mathrm{P}_{1} \mathrm{G}_{\mathrm{i}}\right)$ for $\mathrm{i} \neq 1$

Finally, we can count the loss of Government income and GDP from the Telco sector that occurs due to the notperfect of the spectrum policy.

Next, the maximum value if the internet speed that is achieved at the maximum level of the fairness is according to the equation 14 as follows:

The maximum internet speed $=\mathrm{G}_{\mathrm{i}}^{\mathrm{p}}$

Where $\mathrm{G}_{\mathrm{i}}^{\mathrm{p}}$ is the maximum internet speed.

Then, assume that provider 1 has the highest internet speed, then:

$\mathrm{G}_{1}{ }^{\mathrm{p}}=\mathrm{G}_{1} ;$ And $\mathrm{G}_{\mathrm{i}}^{\mathrm{p}}=\left(\mathrm{G}_{1} \mathrm{P}_{\mathrm{i}}\right) /\left(\mathrm{P}_{1} \mathrm{G}_{\mathrm{i}}\right)$ for $\mathrm{i} \neq 1$

Finally, we can count the potential decreasing of the internet speed that occurs due to the not-perfect of the spectrum policy by calculating the difference between the maximum internet speed (which is obtained if the spectrum policy in this case is perfectly fair) with the existing internet speed (by applying the current spectrum policy).

4.2.2 The Spectrum Policy's Assessment Simulation

Table 5 and 6 show the calculation, then the conclusions of applying the method of "relative equality" to the assessment of the spectrum policy are:

i. The imperfect conditions of "relative equality" between the wireless communication provider's gross revenue and their spectrum license shares will lead to the potential loss of the Country's income and GDP from the telecommunications sector, the greater the unfairness the greater the loss.

ii. In detail, when the "relative equality" is unfair, the loss of the Country's income and GDP of the telecommunication sector is $64.84 \%$ compared to its income and GDP when the "relative equality" is in perfect condition.

The imperfect conditions of "relative equality" between the internet speed and their spectrum license shares will lead to the decreasing of the potential internet speed, the greater the unfairness the greater the decreased. In detail, when the "relative equality" is unfair, then the deceased of the potential internet speed is $68.42 \%$ compared to its speed when the "relative equality" is in perfect condition.

Table 5. Potential Decreasing of the GDP from the Telco's Sector due the Unfair Policy

\begin{tabular}{|c|c|c|c|c|}
\hline \multirow[t]{2}{*}{ Case } & \multicolumn{3}{|c|}{ The Relative Equality Index and the level } & \multirow{2}{*}{$\begin{array}{l}\text { The Potential Loss } \\
\text { of the GDP from } \\
\text { the Telco Sector } \\
\text { (Refer to the Most } \\
\text { Productive } \\
\text { Provider) }\end{array}$} \\
\hline & $\begin{array}{l}\text { Spectrum License Share } \\
\text { (each provider's } \\
\text { spectrum/total licensed) }\end{array}$ & $\begin{array}{c}\text { Provider's } \\
\text { Gross Revenue }\end{array}$ & $\begin{array}{l}\text { the Share of (the } \\
\text { Comparison between } \\
\text { Provider's Revenue and } \\
\text { Provider's spectrum) }\end{array}$ & \\
\hline 1 & Index $=1 ;$ Perfect Level & $\begin{array}{l}\text { Index }=1 ; \\
\text { Perfect Level }\end{array}$ & Index $=1 ;$ Perfect Level & $0.00 \%$ \\
\hline 2 & $\begin{array}{l}\text { Index }=0.9955 ; \text { Fair } \\
\text { Level }\end{array}$ & $\begin{array}{l}\text { Index }=0.9034 ; \\
\text { Fair Level }\end{array}$ & Index $=0.9352 ;$ Fair Level & $-15.21 \%$ \\
\hline 3 & Index $=0.94 ;$ Fair Level & $\begin{array}{l}\text { Index }=0.76 \\
\text { Fair Level }\end{array}$ & $\begin{array}{l}\text { Index }=0.69 ; \text { Unbalanced } \\
\text { Level }\end{array}$ & $-36.36 \%$ \\
\hline 5 & Index $=0.94 ;$ Fair Level & $\begin{array}{l}\text { Index }=0.52 \\
\text { Unbalanced } \\
\text { Level }\end{array}$ & Index $=0.49 ;$ Unfair Level & $-64.84 \%$ \\
\hline
\end{tabular}


Table 6. Potential Decreasing of the Internet Speed due Unfair Policy

\begin{tabular}{|c|c|c|c|c|}
\hline \multirow[t]{2}{*}{ Case } & \multicolumn{3}{|c|}{ The Relative Equality Index and the level } & \multirow[b]{2}{*}{$\begin{array}{l}\text { The Potential } \\
\text { Decreasing of the } \\
\text { internet speed } \\
\text { (Refer to the Most } \\
\text { Fastest Provider) }\end{array}$} \\
\hline & $\begin{array}{l}\text { Spectrum License Share } \\
\text { (each provider's } \\
\text { spectrum/total licensed) }\end{array}$ & $\begin{array}{c}\text { Provider's Average } \\
\text { of the internet } \\
\text { Speed (Mbps) }\end{array}$ & $\begin{array}{c}\text { the Share of } \\
\text { internet speed / } \\
\text { Provider's } \\
\text { spectrum }\end{array}$ & \\
\hline 1 & Index $=1 ;$ Perfect Level & $\begin{array}{l}\text { Index }=1 ; \text { Perfect } \\
\text { Level }\end{array}$ & $\begin{array}{l}\text { Index }=1 ; \text { Perfect } \\
\text { Level }\end{array}$ & $0.00 \%$ \\
\hline 2 & Index $=1 ;$ Perfect Level & $\begin{array}{l}\text { Index }=0.94 ; \text { Fair } \\
\text { Level }\end{array}$ & $\begin{array}{l}\text { Index }=0.94 ; \text { Fair } \\
\text { Level }\end{array}$ & $-33.33 \%$ \\
\hline 3 & Index $=1 ;$ Perfect Level & $\begin{array}{l}\text { Index }=0.72 ; \\
\text { Unbalanced Level }\end{array}$ & $\begin{array}{l}\text { Index }=0.72 ; \\
\text { Unbalanced Level }\end{array}$ & $-51.85 \%$ \\
\hline 4 & Index $=1 ;$ Perfect Level & $\begin{array}{l}\text { Index }=0.49 ; \text { Unfair } \\
\text { Level }\end{array}$ & $\begin{array}{l}\text { Index }=0.49 ; \text { Unfair } \\
\text { Level }\end{array}$ & $-68.42 \%$ \\
\hline
\end{tabular}

\subsection{The Assessment of the Labour Policy}

\subsubsection{The Unemployment Calculation Caused by the Unfair Labour Policy}

In the labour policy assessment using the "relative equality", the disadvantages of the unfair policy is in the form of increased unemployment rates. To explain, the calculation of the equality level of the labour's demand or supply group's share separately is the "self-equality", since the process of calculating the index that only takes into account labour's demand or supply shares separately. Otherwise, the assessment of the fairness level of the employment's policy is the relative equality, since the calculation of the fairness level takes into account the ratio between the labour's supply and demand group's shares. Therefore, there will be any unemployment if the relative equality index is not equal to one, which represents that any difference between the number of people in the pairs of the group demand supply. Although, the total demand equals to the total supply, in the contrary, unemployment remains possible, and the method of "relative equality" suggests that the greater the degree of the unfairness, the greater the unemployment rate. Contrarily, this conclusion is not entirely true in the real world, where there are several possibilities that could happen. The first, there are some workers may be willing to work in the lower class job, of course with the risk of a wage that is lower than working in the classes according to their ability. Consequently, the result is the unemployment rate remains high, consisting of the labour marginalized by the labour that has a higher capacity but not received at the job suited them already filled by the competitor within a class. Secondly, there is a special training and education held by the government for the workers who are not accommodated in the class appropriate for them, but there are the vacancies in a higher job class. It is not always possible solving the problem since the capacity of the people is not necessarily able to receive an education and training.

The potential of the unemployment rate that occurs due to the not-perfect of the labour policy is referred to the equation 16 as follows:

The potential of the unemployment rate $=$ Sum of (difference of supply and demand in the each sector) (16) Table 7. The Impact of The Employment's Country Policy at The Perfect Level to The Potential Unemployment Rate

\begin{tabular}{|c|c|c|c|c|}
\hline Cases & Demand & Supply & Supply To Demand Ratio & $\begin{array}{c}\text { Excess Of The } \\
\text { Labour Supply }\end{array}$ \\
\hline 1 & $\begin{array}{c}\text { Index }=0.07 ; \\
\text { Unfair Level }\end{array}$ & $\begin{array}{c}\text { Index }=0.07 ; \\
\text { Unfair Level }\end{array}$ & Index $=1.00 ;$ Perfect Level & 0 worker $(0 \%)$ \\
\hline 2 & $\begin{array}{c}\text { Index }=0.07 ; \\
\text { Unfair Level }\end{array}$ & $\begin{array}{c}\text { Index }=0.07 ; \\
\text { Unfair Level }\end{array}$ & Index $=0.86 ;$ Fair Level & $\begin{array}{c}2.2 \text { million } \\
\text { Workers }(1.60 \%)\end{array}$ \\
\hline 3 & $\begin{array}{c}\text { Index }=0.07 ; \\
\text { Unfair Level }\end{array}$ & $\begin{array}{c}\text { Index }=0.07 ; \\
\text { Unfair Level }\end{array}$ & Index $=0.62 ;$ Unbalanced Level & $\begin{array}{c}4.8 \text { million } \\
\text { Workers }(3.49 \%)\end{array}$ \\
\hline 4 & $\begin{array}{c}\text { Index }=0.07 ; \\
\text { Unfair Level }\end{array}$ & $\begin{array}{c}\text { Index }=0.07 ; \\
\text { Unfair Level }\end{array}$ & $\begin{array}{c}\text { Index }=0.48 ; \text { Unfair Level (Closed to } \\
\text { the lowest index of the Unbalanced } \\
\text { level })\end{array}$ & $\begin{array}{c}6.4 \text { million } \\
\text { Workers }(4.65 \%)\end{array}$ \\
\hline 5 & $\begin{array}{c}\text { Index }=0.07 ; \\
\text { Unfair Level }\end{array}$ & $\begin{array}{c}\text { Index }=0.07 ; \\
\text { Unfair Level }\end{array}$ & $\begin{array}{c}\text { Index }=0.29 ; \text { Unfair Level (Far to the } \\
\text { lowest index of the Unbalanced level })\end{array}$ & $\begin{array}{c}9.6 \text { million } \\
\text { Workers }(6.98 \%)\end{array}$ \\
\hline
\end{tabular}

Note: Five simulations use the same scenarios, which: (1) there are total demand = supply $=137.5$ million; (2)

Demand and supply are grouped into 11 economic sectors with 3 classes each, so total 33 groups of worker

4.3.2 The Labour Policy's Assessment Simulation

Table 7 shows the resume of the calculation, and then the conclusions of applying the method of "relative equality" to the assessment of the labour policy are: 
i. Even though there is a balance in the demand and supply of labour (nationally), but the imperfect conditions of "relative equality" between demand and supply occurring in each sector or group of workers will cause the potential unemployment.

ii. In detail, at the level of the fairness of the labour policy is perfect will cause the potential for unemployment of $0.0 \%$, at the level of the fairness of the labour policy is fair (the Relative Equality Index of the policy $=0.86$ ) will cause the potential for unemployment of $1.60 \%$, at the level of the fairness of the labour policy is unbalanced (the Relative Equality Index of the policy $=0.62$ ) will cause the potential for unemployment of $3.89 \%$, at the level of the fairness of the labour policy is unfair closed to the lowest index of the unbalanced level (the Relative Equality Index of the policy $=0.48$ ) will cause the potential for unemployment of $4.86 \%$, at the level of the fairness of the labour policy is unfair far to the lowest index of the unbalanced level (the Relative Equality Index of the policy $=0.30$ ) will cause the potential for unemployment of $7.72 \%$.

\subsection{Discussion}

The simulation and analysis prove that the method is appropriate, in the sense that the formula used and the criterion is consistent with the policy performance to be assessed. In brief, here is a summary.

i. Although the losses for the Country and the declining of the Economics' Welfare are relatively large, our prediction an economic policy is unfair are still happening in the most of the countries in the world, to prove it needs more in-depth research using data owned each country that maybe not available in the World bank and UNDP.

ii. Three examples of the implementation of the "Relative Equality" method are deliberately written in the article since each has different characteristics. Here is a discussion on the implementation of this method.

iii. The imperfectness of the level of fairness in the tax policy is the easiest to overcome since there is almost no gap between the theory of fairness and the practice. It is expected that every country that reads this article, only realizes and will be able to directly apply this theory, in the hope of increasing the Government income of $23.39 \%$ to $62.31 \%$.

iv. The imperfections at the level of fairness in the spectrum policy are a bit more difficult to overcome since the losses to the Country resulting from the productivity gap of the operators are not necessarily solved. There is another factor to consider, namely the level of competition between providers. If the most productive provider is the least of its spectrum licenses, then it can be given an additional spectrum in the hope that the Country will directly have prospects for increasing the country's revenue and GDP from the telecommunications sector, although the percentage increase may be smaller than the simulation gives, which is $64.84 \%$. A complicated problem will arise if the most productive provider has already gotten the largest licenses of spectrum licenses, then it will not be given additional spectrum since the potential of this large provider to monopolize the price will be greater.

v. The imperfections at the level of fairness in the labour policy generally occur because of the misscoordination between ministries in a Country. Each country needs to learn more about the problems of manpower in each country are not the same. This article can only be reminded that based on the simulation has been submitted that the unemployment rate can reach $7.72 \%$ if the "Relative Equality" Index is only $30 \%$ even the demand and supply of labour is in an equilibrium country. So the problem of manpower is not just about the balance between demand and supply of labour.

vi. The accumulation of unfair in those three aspects of economic policy exposes to its readers that a Country will experience a financial crisis and a welfare problem if it never cares about the level of justice in its country's policies. At a later date, it is interesting to study the implementation of the theory of fairness in this article on the question of whether the fairness of the local economic policy of some countries could have caused them to come into the crisis, and its crisis creeps up and escalates into a global economic crisis. If the answer is yes, then the problem of unfairness that occurs in one or more countries is a global problem.

\section{CONCLUSION}

The fairness of the economic policies is a compulsion since the more the fairness of the economic policies, the more the health of the Country financially and the Economics' Welfare, contrary, the greater the unfairness, the greater the chances of the crisis of the country. The methods promoted in this article prove to be appropriate for use in planning the Country's perfect policy, being able to measure imperfections on Country policy and taking into account the level of harm to the Country it has incurred, thereby being able to be used to treat an unhealthy Country policy caused by its unfairness Economic policies of that Country.

\section{References}

Wikipedia, the free encyclopedia (2020), "Populism”, https://en.wikipedia.org/wiki/Populism, Cited 20 April 2017. 
Wang, Xiaohu (2015), "The Chinese Economy in Crisis: State Capacity and Tax Reform", Routledge, New York. Mastilo, Z. (2016), "Economic Policy as a Determinant of Development and More Efficient Business Operation in the Republic of Srpska", Business and Management Studies, 2:4, 70-77.

Investopedia (2020), “Gini Index”, http://www.investopedia.com/terms/g/gini-index.asp, Cited 20 April 2017.

Haryadi, Sigit (2017), "Haryadi Index and Its Applications in Science of Law, Sociology, Economics, Statistics, and Telecommunications", Elex Media Komputindo, Jakarta.

Investopedia (2020), "Herfindahl-Hirschman Index", http://www.investopedia.com/terms/h/hhi.asp, Cited 20 April 2017.

Wikipedia, the free encyclopedia (2020), "Herfindahl index”, https://en.wikipedia.org/wiki/Herfindahl_index, Cited 20 April 2017.

The World Bank (2017), "GINI index (World Bank estimate)", http://data.worldbank.org/indicator/SI.POV.GINI?year_high_desc=false\&gclid=CIPAqdvPvtMCFUOhaAo dQiQCNQ, Cited 20 April 2017. 